\title{
Rabbit Vomeronasal Organ-Derivered Cells Have Mesenchymal Profile and Neuronal Commitment
}

\author{
Las Células Derivadas del Órgano Vomeronasal del Conejo \\ tienen Perfil Mesenquimatoso y Compromiso Neuronal
}

\begin{abstract}
Rodrigo S. N. Barreto ${ }^{1}$; Franceliusa Delys de Oliveira $^{1}$; Gustavo de Sá Schiavo Matias ${ }^{1}$; Marcio N. Rodrigues ${ }^{2}$; Rafael C. Carvalho ${ }^{3}$; André Luis R. Franciolli ${ }^{1}$; Paula Fratini ${ }^{1}$ \& Maria Angelica Miglino ${ }^{1}$
\end{abstract}

\begin{abstract}
BARRETO, R. S. N.; DE OLIVEIRA, F. D.; MATIAS, G. S. S.; RODRIGUES, M. N.; CARVALHO, R. C.; FRANCIOLLI, A. L. R.; FRATINI, P. \& MIGLINO, M. A. Rabbit vomeronasal organ-derivered cells have mesenchymal profile and neuronal commitment. Int. J. Morphol., 38(5):1463-1472, 2020.
\end{abstract}

SUMMARY: The vomeronasal organ (VNO) is an accessory organ involved on the olfactory pathway, that detects pheromones and emits signals in order to modulate social and reproductive behavior. The VNO stem cells replace neurons throughout life. The aim of this study was to isolate and characterize cells derived from the vomeronasal organ from New Zealand rabbits. Five male rabbits with 120 days were used for cell isolation and culture. Results: VNO-derived cells presented labelling for proliferation (PCNA), undifferentiated profile (Nanog), neuronal (GFAP), mesenchymal stem cells (CD73, CD90 and CD105 and Stro-1). Also, presence of cytoskeletal (Vimentin, b-tubulin and CK-18) and absence of hematopoietic markers (CD34, CD117 and CD45) both by immunofluorescence and flow cytometry. By PCR it was possible to verify the expression of some undifferentiated profile (Oct-4), neuronal (Nestin) and mesenchymal (CD73, CD105 and Vimentin) genes. Functionally, VNO-derived cells differentiate in vitro into adipocytes, osteocytes and chondrocytes, and presented no tumorigenic potential when injected to Balb/c nu/nu mice. In conclusion, the rabbit VNO-derived cells have a profile that could be supportive to VNO olfactory/neuroreceptor epithelium by delivering factors to epithelial turnover or even by differentiation into epithelial cells to replacement of commissural epithelium.

KEY WORDS: Olfactory System; Olfactory epithelium; Olfactory bulb; Neuronal stem cells.

\section{INTRODUCTION}

Most vertebrates have a vomeronasal system consisting in vomeronasal organ (VNO), accessory olfactory bulb (AOB), vomeronasal amygdala and nerves that connect these structures. The VNO is related to be a social and reproductive structure, involved in communication by molecules, as pheromones, detection and transmission of the signals to central nervous system (Park et al., 2014). It is composed by a pair of tubular structures, situated along the anterior portion of the nasal septum. Medial wall and ventral and dorsal commissures is covered by a sensory neuroreceptor/olfactory epithelium composed by scarce basal cells, receptor cells with apical processes and sustentacular cells. Laterally is covered by a non-sensory typical respiratory epithelium classified as ciliated pseudostratified (Villamayor et al., 2018). Presents on the lamina propria, the vomeronasal glands secrete mucous substances into the luminal surface of sensory epithelia, responsible for pheromones detection (Tomiyasu et al., 2017).

In general, replacement of sensorial cells occurs on sensitive epithelium by vertical migration of cells derived from basal to the apical and sensory cells layer (Monti Graziadei et al., 1980; Moulton et al., 2008). However, the continuous renewal of VNO sensitive cells (even in adulthood) occurs from the ventral and dorsal commissures to the medial wall, and can be regulated by environmental factors (Wilson \& Raisman, 1980; Brann \& Firestein, 2014; Villamayor et al.).

\footnotetext{
${ }^{1}$ Department of Surgery, School of Veterinary Medicine and Animal Science, University of Sao Paulo, Cidade Universitária, Av. Prof. Dr. Orlando Marques de Paiva, 87, São Paulo, SP 05508-270, Brazil.

2 Escola Superior Batista do Amazonas (ESBAM) - Manaus - Amazonas - Brazil.

${ }^{3}$ Federal University of Maranhão (UFMA) - Center of Agricultural and Environmental Sciences. BR 222, Km 04, Boa Vista - Chapadinha - Maranhão - Brazil. 65500-000.
} 
The adult olfactory bulb in one of rare areas that receive neogenerated neurons, even in adulthood, from subventricular zone (SVZ) of lateral ventricules by migration though the rostral migratory stream. Together with SVZ, the subgranular zone (SGZ) of the hippocampus produce neurons that integrate the dentate gyrus granular layer (Pino et al., 2017; Shohayeb et al., 2018). In rodents, near to 20,000 new neuronal progenitors reach, maturate and integrate per day in the adult olfactory bulb, and around $95 \%$ differentiate in granule cells and others in periglomerular neurons (Hardy \& Saghatelyan, 2017). This constant neuronal cell supply guarantees the environmental odor adaptations and the plasticity of olfactory bulb as part of the VNO. Even the morphological characteristics of VNO was studied in several species as rabbit, rat, mice, cats, ruminants and pigs (Park et al.; Villamayor et al.), few studies explored your potential as stem or neuronal precursor cells. Then, this manuscript aimed to isolate and characterize putative neuronal precursors in rabbit VNO parenchyma.

\section{MATERIAL AND METHOD}

Animals: The vomeronasal organ (VNO) was collected from five 120-day old New Zealand male rabbits (Oryctolagus cuniculus) with approximately $3 \mathrm{~kg}$. All animals were treated equally. For tumor formation assay, were used two 60-day old male Balb/c nu/nu mice (Mus musculus). These experiments were approved by the Ethics Committee of the School of Veterinary Medicine and Animal Science of São Paulo University (Protocol number 2337/2011).

Isolation and cell culture. For VNO collection, rabbits were anesthetized with intramuscular injection of $50 \mathrm{mg} /$ $\mathrm{kg}$ of ketamine and $5 \mathrm{mg} / \mathrm{kg}$ of xylazine, and then euthanatized by intracardiac potassium chloride. Then VNO were isolated and washed five times with phosphate buffered saline (PBS) containing $3 \%$ penicillinstreptomycin (\#15140163, Gibco (*)) to remove contaminants. Then, VNO samples were fragmented in explants and then cultured in DMEM/F12 (\#113200338 (*)), High glucose DMEM (\#41965062 (*)) or MEM alpha (\#12571063 (*)) both supplemented $15 \%$ Fetal Bovine Serum (FBS, \#16000044 (*)), 1 \% L-Glutamine (\#25030081 (*)), $1 \%$ Penicillin-Streptomycin, $1 \%$ nonessential amino acids (\#11140050 (*)) and 10-4 M bmercaptoethanol (\#21985023 (*)).

Fibroblast colony-forming unit assay. Was performed as established before (Friedenstein et al., 1976; Owen et al., 1987; Sekiya et al., 2002), the first passage, 103 VNOderived cells were plated on $90 \mathrm{~mm}$ petri dishes (Corning) using the three culture medium conditions, with medium replacement each 2-3 days for 10 days. Then, adherent cells were fixed with paraformaldehyde $4 \%$ (PFA) (Sigma) and stained with crystal violet (Sigma) for $30 \mathrm{~min}$. All experimental procedures were performed in triplicate.

MTT and Trypan blue assays. The colorimetric [3-(4,5dimethylthiazol-2-yl) - 2,5-diphenyltetrazolium bromide (MTT), \#M6494, Invitrogen] assay was performed according to the protocol previously established (Carmichael et al., 1987). In order to verify cellular proliferation, using all medium conditions, $5 \times 103 \mathrm{VNO}-$ derived cells were plated on 96 wells plate and the analysis was performed at 48, 96, 144, 192, 240 and 288 hours. Cells were washed with PBS and $100 \mu \mathrm{l}$ of MTT solution incubated at $37^{\circ} \mathrm{C}$ for 3 hours. Thereafter, was added $50 \mu \mathrm{l}$ of dymethyl sulfoxide (DMSO, \#D12345, Invitrogen) and quantified in a spectrophotometer.

To analyze cells viability, VNO-derived cells cultured in High glucose DMEM were harvested with 0.25 $\%$ trypsin solution each 3 days for 33 days. The results were plotted on a graph using the GraphPad Software.

Immunophenotyping. VNO-derived cells were cultured for 48 hours over coverslips, washed twice with trisbuffered saline solution (TBS) and fixed for 24 hours in PFA $4 \%$. After blocking with $5 \%$ bovine serum albumin, cells were incubated for $1 \mathrm{~h}$ at room temperature with primary antibodies: mouse anti-PCNA monoclonal (\#SC56, Santa Cruz Biotechnology (SCBT)), goat anti-Nanog polyclonal (\#SC-30331, SCBT), anti-GFAP polyclonal (\#SC-33673 SCBT), mouse anti-vimentin monoclonal (\#SC-73259, SCBT), mouse anti-STRO-1 monoclonal (\#SC-47733, SCBT), human anti-b-tubulin monoclonal (\#SC-47751, SCBT), mouse anti-cytokeratin 18 monoclonal (\#SC-32329, SCBT), goat polyclonal CD73 (\#SC-14684, SCBT), anti-mouse CD105 monoclonal (\#SC71042, SCBT), anti-human CD34 monoclonal (\#SC-19621, SCBT), anti-mouse CD90/Thy-1 monoclonal (\#14-090181, Invitrogen) and anti-mouse-CD45 monoclonal (\#F1089-4, Invitrogen). After washing thrice in TBS, goat antimouse (\#A-32723, Invitrogen), donkey anti-goat (\#A11055, Invitrogen) or goat anti-human (\#A-11013, Invitrogen) secondary antibody Alexa Fluor 488 conjugated were incubated for $40 \mathrm{~min}$ at room temperature. Then coverslips were mounted on microscope slides with Vector shield mounting medium and evaluated under epifluorescence Eclipse 800 microscope (Nikon).

Flow cytometry. Flow cytometry was performed using 106 VNO-derived cells, in solution, for each primary antibody (same as used for immunofluorescence). Cells were 
incubated with primary antibody for two hours at $4{ }^{\circ} \mathrm{C}$, washed and followed by incubation with goat anti-mouse (\#A-32723, Invitrogen), donkey anti-goat (\#A-11055, Invitrogen) or goat anti-human (\#A-11013, Invitrogen) secondary antibody Alexa Fluor 488 conjugated. Flowcytometric analysis was performed on a fluorescenceactivated cell sorter.

Osteogenic, adipogenic and chondrogenic differentiation assays. To promote osteogenic differentiation, $104 \mathrm{VNO}$-derived cells were cultured using osteogenic medium, composed of high glucose DMEM supplemented with and $2 \%$ FBS, $50 \mathrm{mM}$ ascorbate-2phosphate (\#113170-55-1, Sigma) and $0.1 \mathrm{mM}$ dexamethasone (\#D4902, Sigma). After 10 days, osteogenic medium was supplemented with $10 \mathrm{mM}$ bglycerolphosphate (\#50020, Sigma). At day 21, cells were washed twice with PBS, fixed for 24 hours in PFA $4 \%$ and stained with Von Kossa, for calcium deposition. Adipogenic differentiation was performed using $104 \mathrm{VNO}$-derived cells plated in 6-well plate using adipogenic differentiation medium, composed of high glucose DMEM supplemented with $2 \%$ FBS, $0.1 \mathrm{mM}$ dexamethasone, $100 \mathrm{mM}$ indomethacin (\#I7378, Sigma), $0.5 \mathrm{mM}$ 1-methyl-3isobutyxanthine (\#I7018, Sigma), $10 \mathrm{mg} / \mathrm{mL}$ insulin (\#I2643, Sigma) and $1 \%$ antibiotic. After 10 days, cells were washed and fixed as described above and stained for Oil Red and Scarlet Sudan to detect intracellular lipid accumulation. Chondrogenic differentiation was carried out using a cell pellet formed with 2 x 106 VNO-derived cells, and cultured with chondrogenic differentiation medium, composed of high glucose DMEM supplemented with $1 \mathrm{x}$ ITS universal cell cultured supplement premix (\#354351, BD), $5.33 \mathrm{mg} / \mathrm{mL}$ linoleic (\#L1376, Sigma), $0.1 \mathrm{mM}$ dexamethasone, $1 \mathrm{mM}$ sodium pyruvate (\#P2256, Sigma), $50 \mathrm{mg} / \mathrm{mL}$ ascorbate-2-phosphate and with transforming growth factor b1 (TGFb1, \#240-B-002, LGC Biotechnology). After 21 days, cell aggregates were embedded in paraffin, sectioned, transferred to glass slides and stained for Masson's Trichrome and Picrosirius.

RNA extraction and conventional PCR. Total RNA was extracted from 2 x 106 VNO-derived cells using TRIzol reagent (\#15596026, Invitrogen), DNA digestion was performed with DNAse I amplification grade (\#18068-015, Life) and cDNA conversion with High Capacity cDNA Reverse Transcription Kit (\#4374967, Life); all following the manufacturer instructions. For PCR reactions, $1 \mu \mathrm{L}$ of cDNA, $0.2 \mu \mathrm{M}$ of each primer, $0.2 \mu \mathrm{m}$ of dNTPs (\#18427088, Invitrogen), 1 unit of Taq DNA Polymerase, $1.5 \mathrm{mM}$ of magnesium chloride and buffer Taq DNA Polymerase (\#10342020, Invitrogen). PCR conditions were: initial denaturation at $94{ }^{\circ} \mathrm{C}$ for 4 min, followed 35 cycles at $94^{\circ} \mathrm{C}$ for denaturation, $1 \mathrm{~min}$ for annealing (temperatures above) and $5 \mathrm{~min}$ at $72^{\circ} \mathrm{C}$ for extension and final extension at $72^{\circ} \mathrm{C}$ for $10 \mathrm{~min}$. PCRs products were separated by 1.5 $\%$ agarose gel electrophoresis, stained with ethidium bromide and visualized by UV transluminator. The following primers were used: CD73 (SH3) SACACGGCATTAGCTGTTATT and ASAAGTATTTGTTCTTTGGGCA $\left(56^{\circ} \mathrm{C}\right)$; CD105(SH2) STCTGGACCACTGGAGAATAC and ASGAGGCATGAAGTGAGACAAT $\left(56^{\circ} \mathrm{C}\right)$; Vimentin SAAGCAGGAGTCCACTGAGTACC and ASGAAGGTGACGAGCCATTTCC $\left(60{ }^{\circ} \mathrm{C}\right)$; OCT-4 SGACAGGGGGAGGGGAGGAGCTAGG and ASCTTCCCTCCAACCAGTTGCCCCAAAC $\left(60^{\circ} \mathrm{C}\right)$; Nestin S-CTCTGACCTGTCAGAAGAAT and ASGACGCTGACACTTACAGAAT $\left(60^{\circ} \mathrm{C}\right)$, and GAPDH SACCACAGTCCATGCCATCAC and ASTCCACCACCCTGTTGCTGTA $\left(60^{\circ} \mathrm{C}\right)$.

Tumorigenic formation in nude mice assay. VNO-derived cells (106) were re-suspended in PBS and intramuscular injected into the left limb of $2 \mathrm{Balb} / \mathrm{c} \mathrm{nu} / \mathrm{nu}$ mice. Every week, for 8 weeks, the animals were clinically examined to identify possible tumor formation. Then, the animals were euthanized following the principles of the Ethical Committee of the School of Veterinary Medicine and Animal Science (intramuscular injection of $50 \mathrm{mg} / \mathrm{kg}$ of ketamine and $5 \mathrm{mg} /$ $\mathrm{kg}$ of xylazine, and then euthanatized by intracardiac potassium chloride) and samples from the biceps, liver, lung, kidney, and cardiac muscle tissue were collected and fixed in PFA $4 \%$. Tissues for histopathology were embedded in paraffin and sectioned at $5 \mu \mathrm{m}$, transferred to glass slides, stained for hematoxylin and eosin, and analyzed at Eclipse E-800 microscope (Nikon).

\section{RESULTS}

VNO-derived cell morphology. Until day five of culture, the release of cells from explant was discrete, however was possible to see cells attached to the plate (Fig. 1 A-C), independently of the used media. The presence of small colonies of adherent cells was observed after 10 days of culture (Fig. 1 D-F). After day 15 of culture a great number of cells were evident (Fig. 1 G-I) and after day 20 acquired fibroblastoid shape, prevailing the homogeneity of the colonies (Fig. $1 \mathrm{~J}-\mathrm{L}$ ). At day 25, only small fibroblastoid cells were observed reaching plate confluence and the first cells passage was performed.

Colony forming units-fibroblastic assay (CFU), activity and cellular viability. Independent of the media, the VNO- 

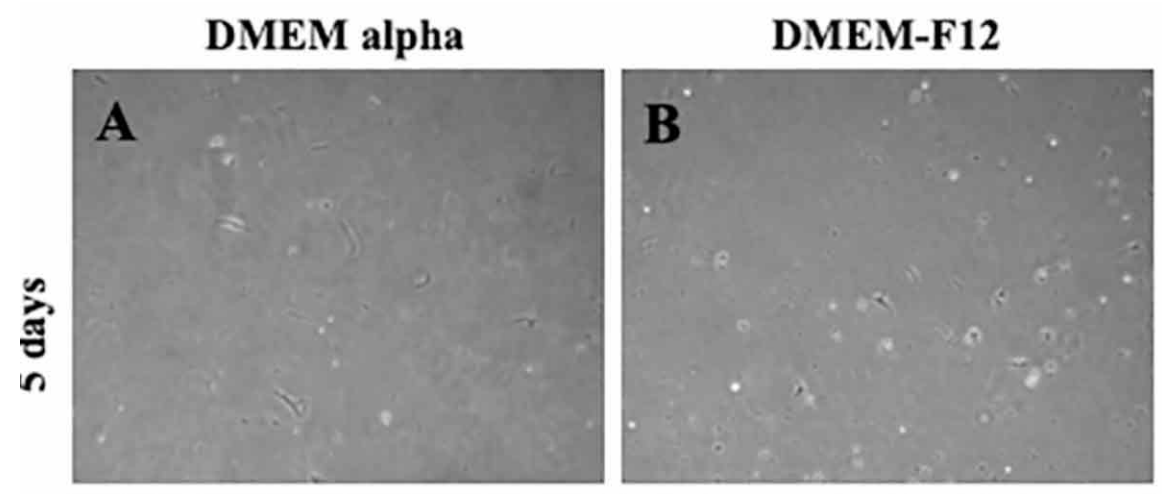

\section{High Glucose DMEM}
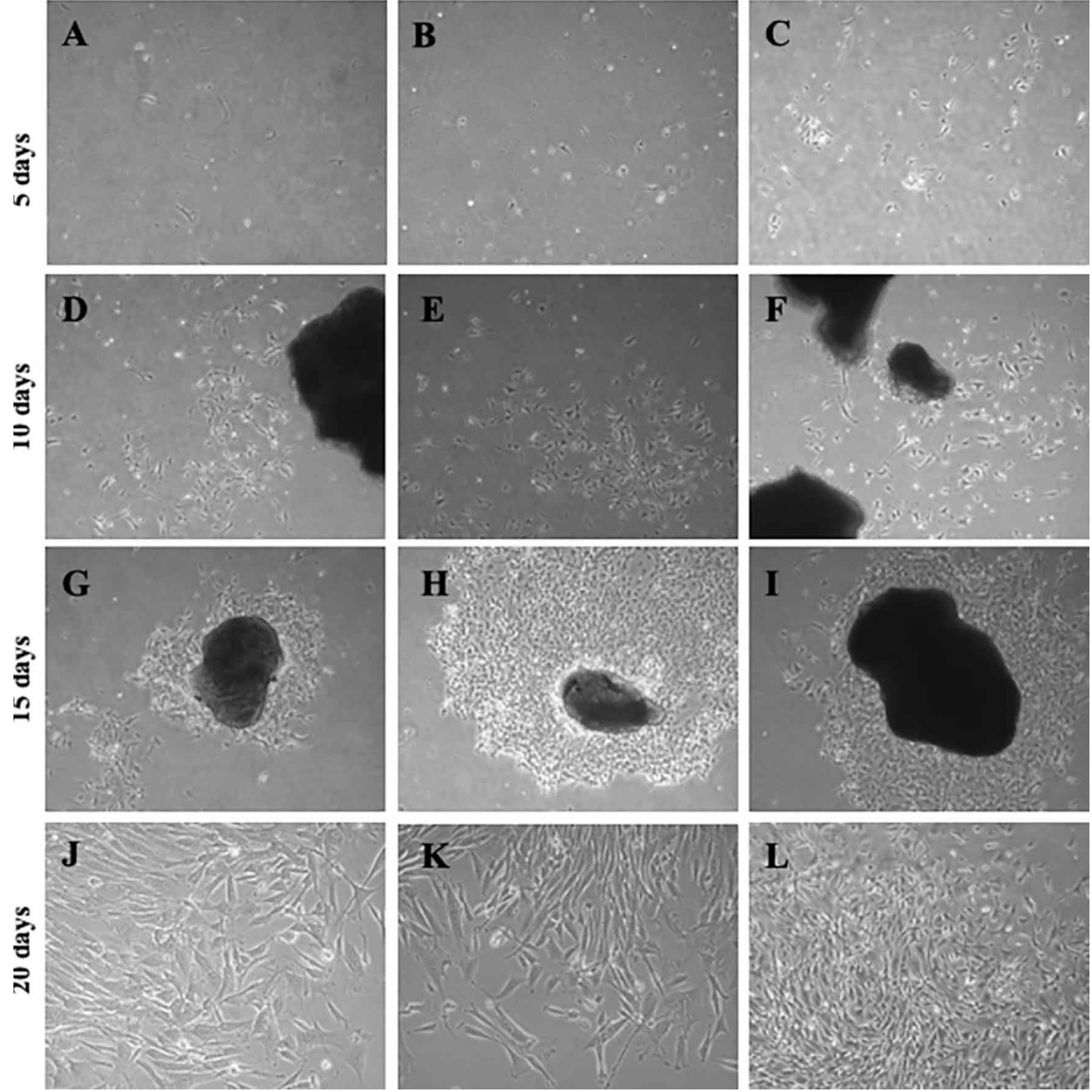

Fig. 1. Morphology of VNO-derived cell cultured with different media and periods. At day 5, discrete cell release from explant (A-C). Beginning of colonies formation at day 10 (D-F). Colonies with large number of cells at day 15 (G-I). Cells acquired fibroblastoid shape (J-L).

derived cells were able to generate around 46 colonies per 103 plated cells (Fig. 2 A-B). In MTT assay, it was found that High Glucose DMEM was the better medium for cells growth during the evaluation period of 12 days. DMEM/F12 medium decreased cells growth around the eighth day and after this increased again during the next days (Fig. 2C). In Alpha-MEM 
medium cells grew between the first and second analysis, decline between the second and third analysis and, increase again gradually during successive stages (Fig. 2C). Then High Glucose DMEM was selected as the medium to all other experiments. In the viability analysis with trypan blue, it was verified that the number of living cells increased over time. It was possible to verify exponential growth of these cells during the observed period (Fig. 2D).

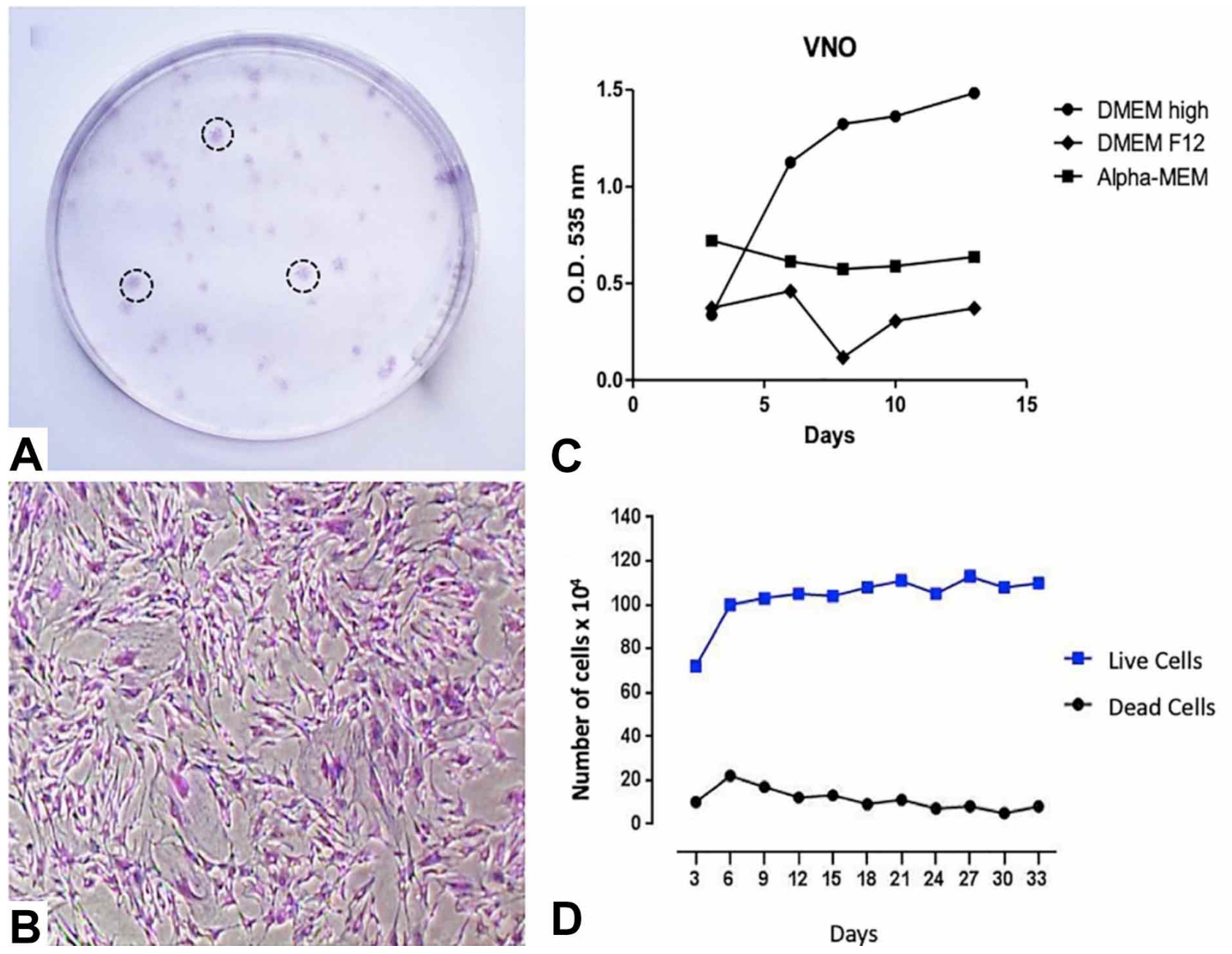

Fig. 2. Colony forming units-fibroblastic assay (CFU), activity and cellular viability of VNO-derived cells. (A) colony formation delimited by dashed circle and stained with crystal violet. (B) magnification of colony showed in A. (C) MTT assay for different media culture conditions, evidencing exponential growth in high glucose DMEM. (D) Live and dead cell number stained by trypan blue in high glucose DMEM cultured VNO-derived cells.

Presence of mesenchymal and neuronal markers. By immunofluorescence and flow cytometry, were observed presence of markers for proliferation (PCNA), undifferentiated profile (NANOG), neuronal lineages (GFAP), mesenchymal stem cells (CD73, CD90, CD105 and STRO-1) and cytoskeletal (Vimentin, b-tubulin and CK-18). In addition, hematopoietic markers (CD34 and CD45) were absent in the VNO-derived cells (Fig. 3). Some proteins were selected to have their gene expression qualitatively analyzed, then CD73, CD105, vimentin, OCT4, nestin detection were in accordance with protein presence (Fig. 3).
Differentiation and tumorigenic formation in nude mice assay. VNO-derived cells were inducted to adipogenic, chondrogenic and osteogenic differentiation. After 21 days of adipogenic differentiation was possible to observed VNO-derived cells differentiated into adipocyte lineage, by lipid cytoplasmic vacuoles stained in red by Oil Red and Scarlet Sudan techniques (Fig. 4A). Furthermore, after 21 days of osteogenic differentiation was possible to observe VNO-derived cells acquiring polygonal morphology with large cytoplasm filled with vacuoles instead of fibroblastoid shape, also bone extracellular matrix 

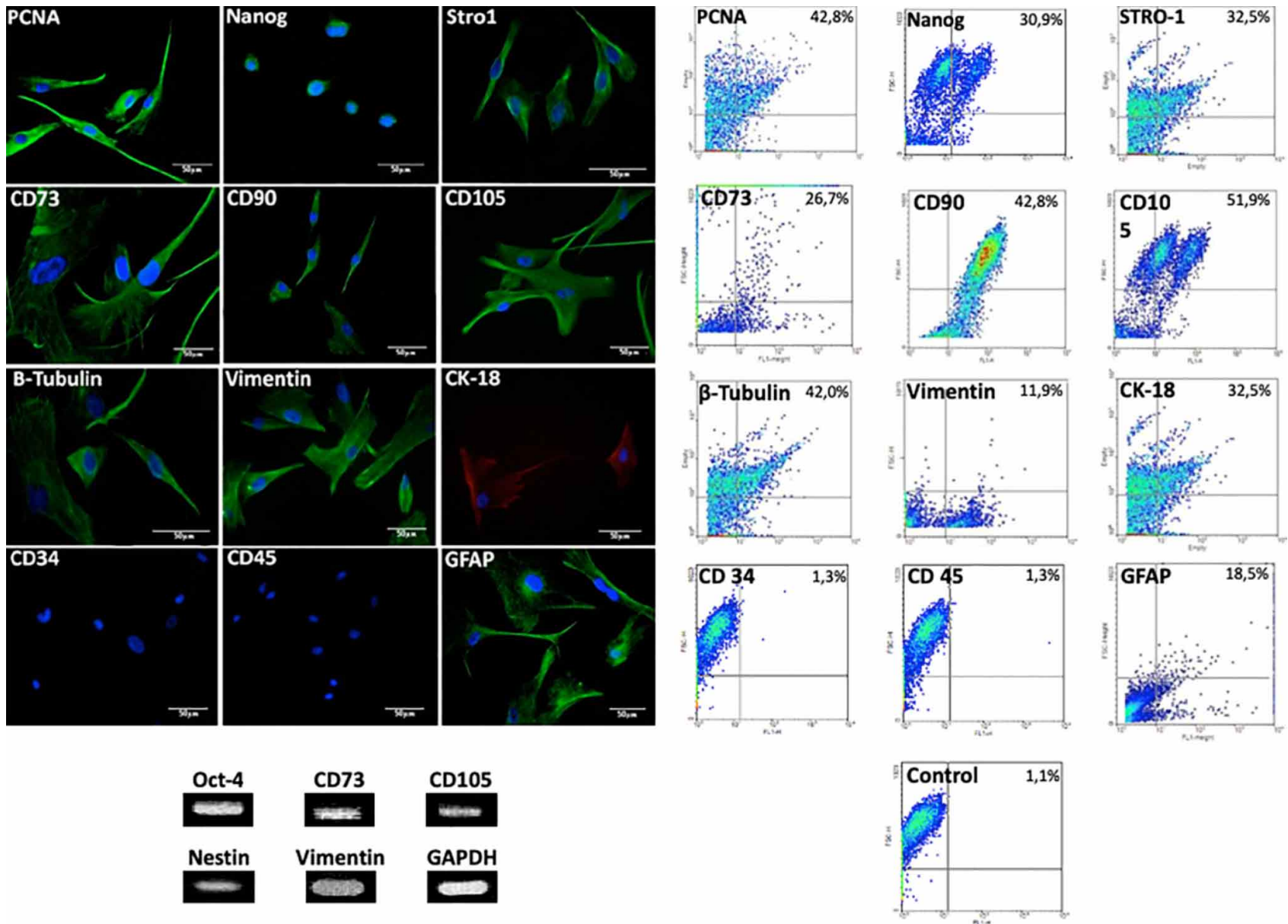

Fig. 3. Presence of mesenchymal and neuronal markers by immunofluorescence, flow citometry and PCR. Labeling of markers for proliferation (PCNA), undifferentiated profile (Nanog), mesenchymal stem cells (CD73, CD90, CD105 and STRO-1), cytoskeletal (Vimentin, b-tubulin and CK-18) and neuronal lineages (GFAP). And absence of hematopoietic markers (CD34, CD117 and CD45).

formation was observed by calcium granules staining by Von Kossa technique (Fig. 4B). For chondrogenic differentiation, by histology, were possible to detect that VNO-derived cell changed their shape to be chondrocytelike with large amount of collagen fibers interposed inbetween, evidenced by Masson's Trichrome and Picrosirius staining (Fig. 4C). For tumorigenic formation in the Balb/ c nu/nu mice, biceps, liver, lung, kidney, and heart were histopathologicaly analyzed after 60 days of VNO-derived cells injection, and no tumor formation was observed in any organ analyzed (Fig. 5).

\section{DISCUSSION}

Herein we showed that rabbit VNO could be a favorable source of mesenchymal cells that is easy to isolate and culture, and have some neuronal markers, such as nestin and GFAP. The VNO luminal surface is covered by two different epithelia, in the lateral part is the respiratory epithelia, and the medial part and commissures are covered by the neuroreceptor or olfactory epithelium (Villamayor et al.). The rabbit VNO-derived cells have a homogeneous fibroblastoid morphology with capability to form colonies, as similarity as described by others for murine (Friedenstein et al.; Murrell et al., 2009; Wetzig et al., 2011) or rabbit (Ercolin et al., 2016) olfactory epithelium.

The PCNA labelling indicates a proliferative status of those cells, and after 5 days of culture the cells increase their metabolism and the number of live cells, when cultured in high glucose DMEM. Those parameters enforce that rabbit VNO-derived cells are easy to obtain and to maintain in culture, some favorable aspects to be used as cell therapy (Ercolin et al.; Borghesi et al.,2017). 

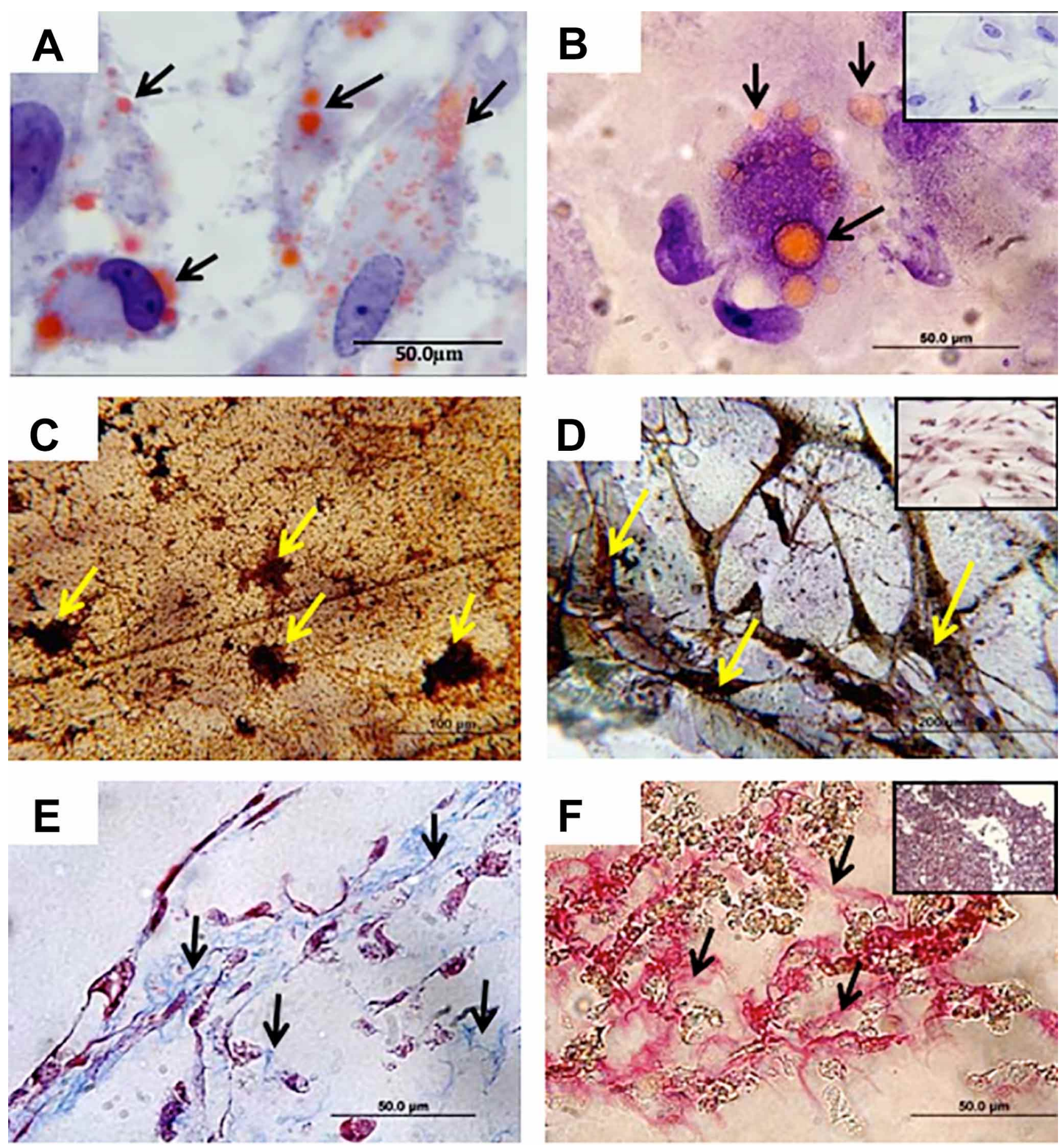

Fig. 4. Differentiation and tumorigenic formation in nude mice assay. Adipogenic differentiation stained with Oil Red (A) and Sudam Scarlet (B), note the deposition of lipid droplets (arrows). In (C) osteogenic differentiation stained with Von Kossa observe deposition of calcium colored in black (arrows). In (D) magnification of C. In (E-F) Chondrogenic differentiation stained by Masson's Trichrome and Picrosirus, note the collagen fibers deposition (arrows). In the upper right edge of the image B, D and $\mathrm{F}$ are the controls.

As stated by Parolini et al. (2008), mesenchymal stem cells need to be adherent to plastic, express CD105, CD73 and CD90; lack expression of hematopoietic markers (such as CD45 and CD34); and also, be able to differentiate to osteoblasts, adipocytes and chondroblasts. As our VNOderived cells attended those parameters, we can suggest that 
they have mesenchymal profile. Moreover, those cells are unable to be tumorigenic when injected in immunodeficient
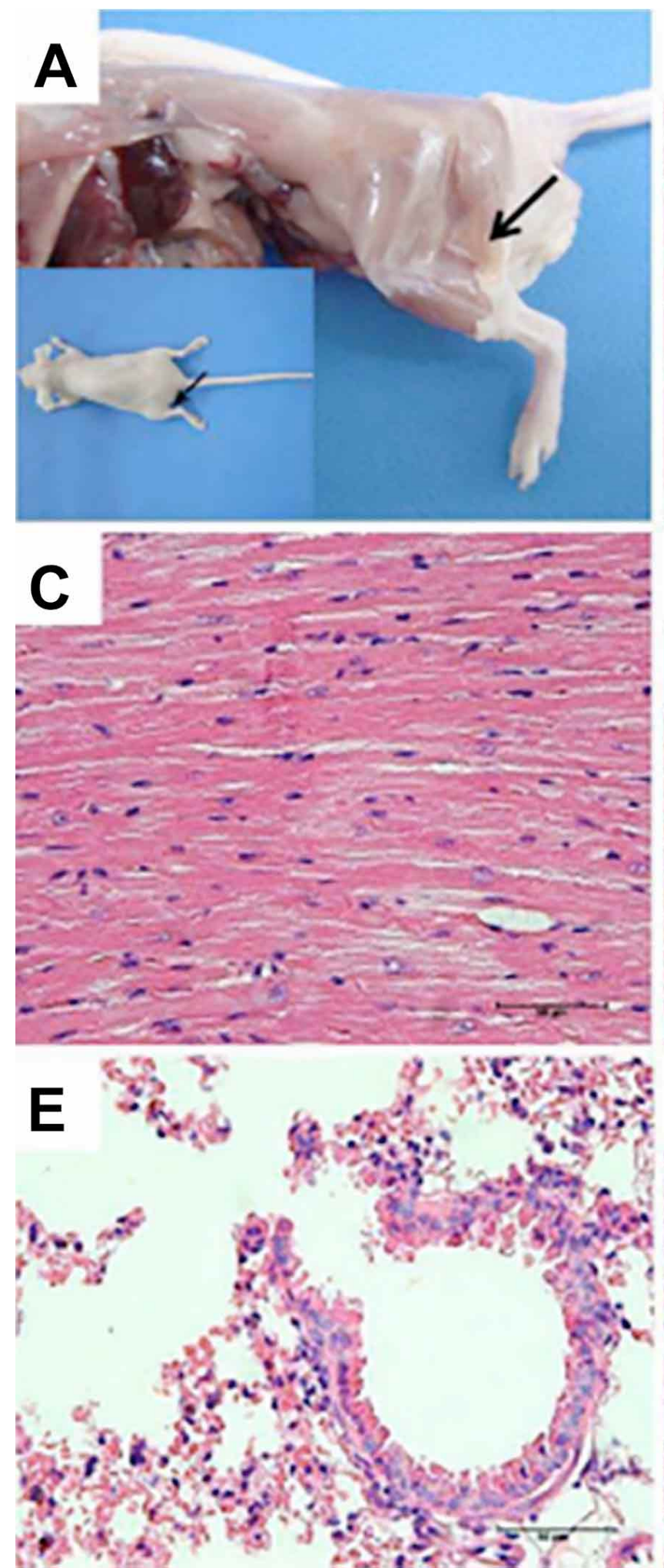

mice, been saved to cell therapy use[U1] (Tropel et al., 2004).
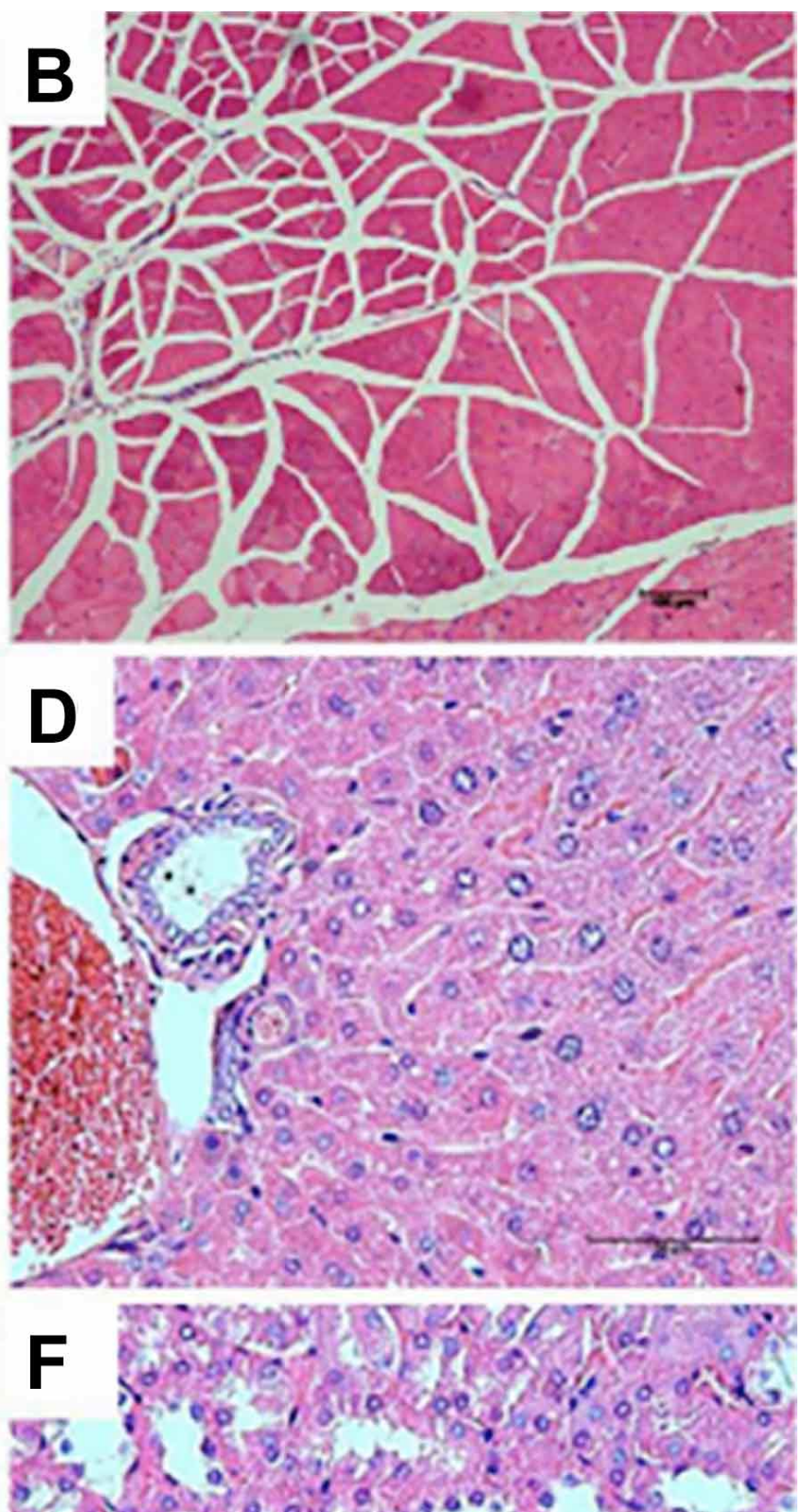

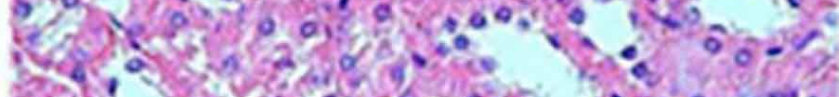
2.3.

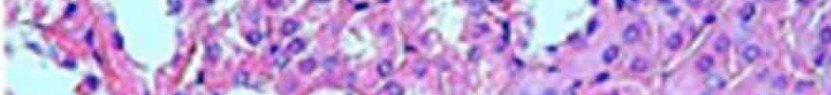

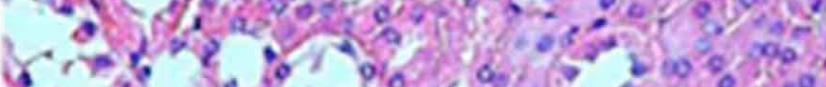

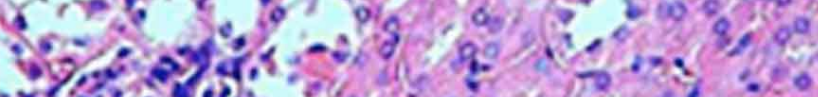

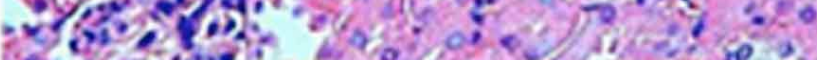

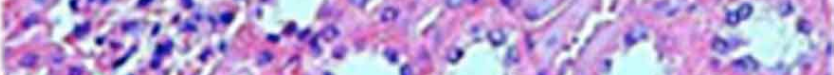

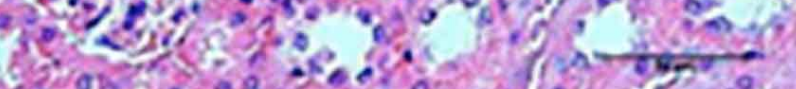

Fig. 5. Tumorigenic potential of the VNO cells in immunocompromised nude mice. No alterations were found in hind limb inoculation (arrow, A), skeletal muscle (B), cardiac muscle (C), liver (D), lung (E) and kidney (F). 
Another characteristic of the rabbit VNO-derived cells is the presence of some pluripotent markers at mRNA and protein levels (OCT4 and NANOG), indicating a partial undifferentiated profile of those cells, because complete undifferentiated profile is regulated by OCT4, SOX2, KLF4 e C-MYC co-expression (Táncos et al., 2015). Also, NANOG activates the OCT4 promoter region, then they coexpression given a less restrictive differentiation potential to mesenchymal cells (Pei et al., 2018; Yang et al., 2018).

Those cells have higher expression of CK-18 than vimentin, that imbalance of cytoskeletal markers could indicate mesenchymal-epithelial transition (MET). The epithelial-mesenchymal/mesenchymal-epithelial transition (EMT/MET) are events that occur physiologically in reparative and/or proliferative tissues and in association with stem cells, such as mesenchymal ones (Li et al., 2011). Also, those events on mesenchymal cells are necessary to permit proliferation, migration and differentiation (Li et al.). In the VNO there is a constant turnover of epithelial cells from commissures to medial wall, requiring a continuous replacement of commissural cells (Villamayor et al.), then VNO-derived cell, as mesenchymal profile and possibly in MET, could support the VNO olfactory epithelium.

On VNO medial parenchyma, the connective tissue surrounds the unmyelinated nerves and supports the sensorial epithelium, then shares some markers with those two tissues, such as neuroreceptors (Gai2, $\mathrm{GaO}$ ) and olfactory marker protein (Villamayor et al.). Furthermore, in our results, the VNO-derived cells that have parenchymal characteristics also presented neuronal markers, such as Nestin and GFAP, that also indicate that those cells could derivate from a neuronal lineage and be supportive to olfactory/neuroreceptor epithelium. In conclusion, the rabbit VNO-derived cells have a marker profile that could be supportive to VNO olfactory/neuroreceptor epithelium by delivering factors to epithelial turnover, or even by differentiation into epithelial cells to replacement of commissural epithelium.

ACKNOWLEDGEMENTS. This work was supported by The São Paulo Research Foundation [FAPESP, grant number 12/11560-4].

BARRETO, R. S. N.; DE OLIVEIRA, F. D.; MATIAS, G. S. S.; RODRIGUES, M. N.; CARVALHO, R. C.; FRANCIOLLI, A. L. R.; FRATINI, P. \& MIGLINO, M. A. Las células derivadas del órgano vomeronasal del conejo tienen perfil mesenquimatoso y compromiso neuronal. Int. J. Morphol., 38(5):1463-1472, 2020.
RESUMEN: El órgano vomeronasal (OVN) es un órgano accesorio de la vía olfatoria, que detecta feromonas y emite señales que afectan la modulación del comportamiento social y reproductivo. Las células madre OVN reemplazan las neuronas durante toda la vida. El objetivo de este estudio fue aislar y caracterizar células derivadas del órgano vomeronasal de conejos raza Nueva Zelanda. Para el aislamiento y el cultivo celular se utilizaron cinco conejos machos con una edad de 120 días. Las células del OVN presentaron etiquetado para la proliferación (PCNA), un perfil indiferenciado (Nanog), neuronal (GFAP), células madre mesenquimales (CD73, CD90 y CD105 y Stro-1). Además, se observó presencia de citoesqueleto (Vimentina, $\beta$-tubulina y CK-18) y ausencia de marcadores hematopoyéticos (CD34, CD117 y CD45) tanto por inmunofluorescencia como por citometría de flujo. Mediante PCR fue posible verificar la expresión de algunos genes de perfil indiferenciado (Oct-4), neuronal (Nestin) y mesenquimatoso (CD73, CD105 y Vimentin). Las células derivadas del OVN se diferencian in vitro en adipocitos, osteocitos y condrocitos, y no presentan un potencial tumorigénico al ser infiltrados en ratones Balb / c nu / nu. En conclusión, las células derivadas de OVN de conejo tienen un perfil que podría ser compatible con el epitelio olfatorio / neurorreceptor de OVN transmitiendo factores al recambio epitelial o incluso mediante la diferenciación en células epiteliales para reemplazar el epitelio comisural.

PALABRAS CLAVE: Sistema olfativo; Epitelio olfativo; Bulbo olfatorio; Células madre neuronales.

\section{REFERENCES}

Borghesi, J.; Mario, L. C.; Carreira, A. C. O.; Miglino, M. A. \& Favaron, P. O. Phenotype and multipotency of rabbit (Oryctolagus cuniculus) amniotic stem cells. Stem Cell Res. Ther, 8(1):27, 2017.

Brann, J. H. \& Firestein, S. J. A lifetime of neurogenesis in the olfactory system. Front. Neurosci., 8:182, 2014.

Carmichael, J.; DeGraff, W. G.; Gazdar, A. F.; Minna, J. D. \& Mitchell, J. B. Evaluation of a tetrazolium-based semiautomated colorimetric assay: assessment of radiosensitivity. Cancer Res., 47(4):943-6, 1987.

Ercolin, A. C. M.; Roballo, K. C. S.; Casals, J. B.; Pieri, N. C. G.; Souza, A. F.; Barreto, R. S. N.; Bressan, F. F:; Feitosa, M. L. T.; Miglino, M. A.; Meirelles, F. V.; et al. Rabbit olfactory stem cells. Isolation protocol and characterization. Acta Cir. Bras., 31(1):59-66, 2016.

Friedenstein, A. J.; Gorskaja, J. F. \& Kulagina, N. N. Fibroblast precursors in normal and irradiated mouse hematopoietic organs. Exp. Hematol., 4(5):267-74, 1976.

Hardy, D. \& Saghatelyan, A. Different forms of structural plasticity in the adult olfactory bulb. Neurogenesis (Austin), 4(1):e1301850, 2017.

Li, B.; Zheng, Y. W.; Sano, Y. \& Taniguchi, H. Evidence for mesenchymalepithelial transition associated with mouse hepatic stem cell differentiation. PLoS One, 6(2):e17092, 2011.

Monti Graziadei, G. A.; Karlan, M. S.; Bernstein, J. J. \& Graziadei, P. P. Reinnervation of the olfactory bulb after section of the olfactory nerve in monkey (Saimiri sciureus). Brain Res., 189(2):343-54, 1980.

Moulton, D. G.; Çelebi, G. \& Fink, R. P. Olfaction in Mammals-Two Aspects: Proliferation of Cells in the Olfactory Epithelium and Sensitivity to Odours. In: Wolstenholme, G. E. W. \& Knight, J. (Eds.) Ciba Foundation Symposium - Internal Secretions of the Pancreas (Colloquia on Endocrinology). Novartis Foundation Symposia, 2008. pp.227-50. 
Murrell, W.; Sanford, E.; Anderberg, L.; Cavanagh, B. \& Mackay-Sim, A. Olfactory stem cells can be induced to express chondrogenic phenotype in a rat intervertebral disc injury model. Spine J., 9(7):585-94, 2009.

Owen, M. E.; Cavé, J. \& Joyner, C. J. Clonal analysis in vitro of osteogenic differentiation of marrow CFU-F. J. Cell Sci., 87(Pt. 5):731-8, 1987.

Park, C.; Ahn, M.; Lee, J. Y.; Lee, S.; Yun, Y.; Lim, Y. K.; Taniguchi, K. \& Shin, T. A morphological study of the vomeronasal organ and the accessory olfactory bulb in the Korean roe deer, Capreolus pygargus. Acta Histochem., 116(1):258-64, 2014.

Parolini, O.; Alviano, F.; Bagnara, G. P.; Bilic, G.; Bühring, H. J.; Evangelista, M.; Hennerbichler, S.; Liu, B.; Magatti, M.; Mao, N.; et al. Concise review: isolation and characterization of cells from human term placenta: outcome of the First International Workshop on Placenta Derived Stem Cells. Stem Cells, 26(2):300-11, 2008.

Pei, W.; Lu, T.; Wang, K.; Ji, M.; Zhang, S.; Chen, F.; Li, L.; Li, X. \& Guan, W. Biological characterization and pluripotent identification of ovine amniotic fluid stem cells. Cytotechnology, 70(3):1009-21, 2018.

Pino, A.; Fumagalli, G.; Bifari, F. \& Decimo, I. New neurons in adult brain: distribution, molecular mechanisms and therapies. Biochem. Pharmacol., 141:4-22, 2017.

Sekiya, I.; Larson, B. B. L.; Smith, J. J. R.; Pochampally, R.; Cui, J. G. \& Prockop, D. J. Expansion of human adult stem cells from bone marrow stroma: conditions that maximize the yields of early progenitors and evaluate their quality. Stem Cells, 20(6):530-41, 2002.

Shohayeb, B.; Diab, M.; Ahmed, M. \& Ng, D. C. H. Factors that influence adult neurogenesis as potential therapy. Transl. Neurodegener., 7:4, 2018.

Táncos, Z.; Bock, I.; Nemes, C.; Kobolák, J. \& Dinnyés, A. Cloning and characterization of rabbit POU5F1, SOX2, KLF4, C-MYC and NANOG pluripotency-associated genes. Gene, 566(2):148-57, 2015.

Tomiyasu, J.; Kondoh, D.; Sakamoto, H.; Matsumoto, N.; Sasaki, M.; Kitamura, N.; Haneda, S. \& Matsui, M. Morphological and histological features of the vomeronasal organ in the brown bear. J. Anat., 231(5):749-57, 2017.

Tropel, P.; Noël, D.; Platet, N.; Legrand, P.; Benabid, A. L. \& Berger, F. Isolation and characterisation of mesenchymal stem cells from adult mouse bone marrow. Exp. Cell Res., 295(2):395-406, 2004.

Villamayor, P. R.; Cifuentes, J. M.; Fdz-de-Troconiz, P. \& SanchezQuinteiro, P. Morphological and immunohistochemical study of the rabbit vomeronasal organ. J. Anat., 233(6):814-27, 2018.

Wetzig, A.; Mackay-Sim, A. \& Murrell, W. Characterization of olfactory stem cells. Cell Transplant., 20(11-12):1673-91, 2011.

Wilson, K. C. \& Raisman, G. Age-related changes in the neurosensory epithelium of the mouse vomeronasal organ: extended period of postnatal growth in size and evidence for rapid cell turnover in the adult. Brain Res., 185(1):103-13, 1980.

Yang, P. J.; Yuan, W. X.; Liu, J.; Li, J. Y.; Tan, B.; Qiu, C.; Zhu, X. L.; Lai, D. M.; Guo, L. H. \& Yu, L. Y. Biological characterization of human amniotic epithelial cells in a serum-free system and their safety evaluation. Acta Pharmacol. Sinica, 39:1305-16, 2018.
Corresponding author:

Maria Angelica Miglino

Av. Prof. Orlando Marques de Paiva, 87

CEP: $05508-270$

Cidade Universitária

Butantã

São Paulo, SP

BRAZIL

Email: miglino@usp.br

Received: 27-03-2020

Accepted: 02-05-2020 